\title{
Anatomia władzy. Mistewicz kontra Karnowski. 2010. Wydawnictwo Czerwone i Czarne, ss. 304
}

Tomunikowanie polityczne jest jednym z najbardziej intrygujących aspektów komunikacji społecznej. Co roku na polskim rynku wydawniczym pojawiają się pozycje, których autorzy podejmują próby opisu i analizy tego złożonego procesu, a także zmian, jakim owo zjawisko podlega w związku z dynamicznym rozwojem nowych mediów. Rekomendowana tu publikacja jest bez wątpienia szczególna. Przede wszystkim to pierwsza w Polsce książka wideo. W trakcie lektury czytelnik ma możliwość obejrzenia m.in. wywiadów, debat, wydarzeń, do których Michał Karnowski i Eryk Mistewicz odnoszą się w swojej dyskusji. Próżno w niej szukać naukowych teorii, pozycja ta jest zbiorem siedmiu niezwykle ciekawych i inspirujących rozmów, będących zestawieniem różnych doświadczeń, różnych postaw i poglądów związanych z polityką w XXI wieku. W debacie podjętej w tej książce są przedstawione ciekawe, a zarazem mało dostępne dla przeciętnego obywatela mechanizmy zdobywania władzy i tworzenia relacji między dziennikarzami a politykami.

Anatomia władzy to konfrontacja dwóch zupełnie odmiennych postaw, całkowicie różnego podejścia do polityki. Prowadzona przez Karnowskiego rozmowa z Mistewiczem jest pełna czasem skrajnie różniących się opinii. Karnowski, o czym sam pisze we wstępie, staje po stronie starej, tradycyjnej polityki, Mistewicz jest orędownikiem nowego modelu jej uprawiania. Ów nowy model opiera się w dużym stopniu na wysokim poziomie umiejętności komunikacyjnych i marketingowych. W pierwszej rozmowie Mistewicz analizuje poszczególne wydarzenia polityczne i omawia w ich kontekście działania komunikacyjne poszczególnych partii, koncentrując się przede wszystkim na Prawie i Sprawiedliwości oraz Platformie Obywatelskiej. Konstatuje on, że standardowe działania public relations to w dzisiejszych czasach, w których „mamy do czynienia z gigantycznym niedoborem uwagi odbiorców, za który dziś marketerzy są w stanie płacić każde pieniądze - za chwilę uwagi" [Anatomia władzy... 2010: 138], zdecydowanie za mało. Konieczna jest zatem implementacja założeń marketingu narracyjnego. Pojęcie to, zaproponowane zresztą przez samego Mistewicza, oznacza nic innego jak umiejętność zdobywania i utrzymywania wyborców przez odpowiednio przygotowaną i wdrożoną narrację, historię kandydata. Uwagi Mistewicza spotykają się w toku dyskusji z dużym sprzeciwem Karnowskiego. Wobec wszechogarniającego politykę marketingu Karnowski stara się znaleźć jej sedno, jej sens, który 
- zdaje się - polityka dawno już utraciła. Doszukuje się więc w niej wartości, planów, idei. Mistewicz zaś dokonuje zimnej, pragmatycznej analizy działań partii i polityki, uwzględniając przede wszystkim ich skuteczność w wywieraniu wpływu na otoczenie, w budowaniu emocji.

Z dyskusji tej wyłania się specyficzny obraz polityki i samych polityków. Czytelnik może wraz z pogłębianiem lektury doznać wręcz uczucia wszechogarniającego zakłamania, okazuje się bowiem, że politycy są od samego początku do końca wyreżyserowani. Czytelnik może mieć zatem wrażenie, że uczestniczy niemal w teatrze, a także dojść do skądinąd wcale nieodosobnionego wniosku, że marketingu w polityce jest za dużo, a nawet, że jest on swoistym zagrożeniem. Atmosfera podejmowanych w tej książce dyskusji, przytaczane argumenty doskonale oddają nastroje towarzyszące zagadnieniom związanym z komunikacją i marketingiem w polityce w ogóle. Trzeba zauważyć bowiem, że obserwujemy obecnie dwa zjawiska: (1) dynamiczny rozwój marketingu politycznego, któremu paradoksalnie towarzyszy (2) spadek zainteresowania polityką. Stąd też wielu komentatorów przyczyn drugiego wspomnianego zjawiska upatruje w tym pierwszym. To zaś prowadzi często do formułowania poglądów, według których między marketingiem politycznym oraz public relations a propagandą jest stawiany znak równości. Konsekwencją takiego zabiegu jest oczywiście pejoratywne naznaczenie dwóch pierwszych spośród wskazanych powyżej pojęć. Z punktu widzenia teorii marketingu politycznego trudno zgodzić się z takim wnioskowaniem. W sytuacji, w której obserwujemy ciągle wysoki poziom chwiejności wyborczej, a co za tym idzie - duży deficyt identyfikacji z partiami politycznymi, marketing polityczny daje skuteczne narzędzia do zdobywania, ale i utrzymywania władzy. Co do zasady, trudno doszukiwać się czegoś niestosownego w tym, że politycy chętniej z tych narzędzi korzystają. Problem pojawia się wówczas, kiedy poza działaniami marketingowymi nie mają oni do zaproponowania konkretnej oferty programowej.

Zdaniem Mistewicza: „dziś nie ma polityki bez ludzi, bez opowiedzenia ich emocji za sobą. Emocji, a nie tylko merytorycznej argumentacji [Anatomia władzy... 2010: 48-49]. Innymi słowy, wielkie programy i idee będą zasadniczo bezużyteczne bez odpowiedniej oprawy komunikacyjnej, a doskonałą egzemplifikacją tego twierdzenia są losy Unii Wolności [zob. Wincławska 2010]. Niezrozumienie zasad rządzących komunikowaniem politycznym w dzisiejszym świecie lub też nieumiejętne korzystanie z niego może prowadzić do dotkliwych porażek. W tym kontekście na szczególną uwagę zasługuje rozmowa o nowej erze w marketingu. Konstatacje, które płyną z tej dyskusji, są jednoznaczne, nie może być mowy o sukcesie bez implementacji nowej strategii marketingowej, opartej właśnie na owej narracji. Reklama należy zatem, zdaniem Mistewicza, do metod konwencjonalnych i drogich, które w dzisiejszych czasach mniej się sprawdzają. Stanowisko takie nie jest zaskoczeniem, już od dłuższego czasu bowiem pisze się i mówi sporo o upadku reklamy. Jednakże z drugiej strony należy zwrócić uwagę, że reklama 
cały czas funkcjonuje, a gdyby była nieefektywna, to nie byłoby tylu zainteresowanych. Wydaje się zatem, że opinię Mistewicza można by uzupełnić o stwierdzenie, że reklama jako główny kanał komunikacji jest zdecydowanie niewystarczająca i daje najmniej możliwości budowania relacji, zwłaszcza w polityce.

W dyskusji o komunikacji politycznej, zwłaszcza w jej wymiarze praktycznym, w jakim czynią to autorzy, nie może zabraknąć rozważań o roli dziennikarzy, a głównie o ich wpływie na politykę, na sposób jej komunikowania. Polityka podlega bowiem procesowi mediatyzacji, czyli inaczej rzecz ujmując, poddaje się niejako logice działania mediów, znając ich ogromną siłę oddziaływania. Politycy i partie muszą zatem generować takie przekazy, aby zainteresować tym media. Działa prosty mechanizm wzmacniania zachowań oczekiwanych - jeśli politycy widzą, że pewne określone formy przekazu przynoszą zamierzony efekt, będą je stosować kolejny raz. Jednakże kształtowanie relacji z mediami jest trudne. Sposób przedstawiania treści, ich interpretacje mogą zmienić zupełnie sens przekazu, na jakim zależało politykom. Mistewicz i Karnowski poruszają ten ważny wątek. Przy czym w świecie prezentowanym przez Mistewicza rola dziennikarzy zmienia się. Dzięki najnowszym technologiom politycy mają możliwość pomijania dziennikarzy i kierowania swojego przekazu bezpośrednio do wyborców. Dobrze obrazuje to następująca wypowiedź Mistewicza: „politycy szukają pomysłu, aby ze swoim przekazem dotrzeć bezpośrednio do finalnego odbiorcy [...] jeśli politycy [...] podchodzą z ograniczonym zaufaniem do mediów, jeśli szukają obejścia w obiegu informacji, sposobów wytworzenia bezpośrednich kanałów komunikacji z odbiorcą, to właśnie dlatego, aby nie być zakładnikami mediów" [Anatomia władzy... 2010: 77]. Mistewicz mówi więc, że jego zdaniem kończy się czas, w którym media mają władzę na politykami. Szansą na to, aby relacje w wyborcami zyskały nową jakość, są rzecz jasna nowe media. Wątek ten jest w recenzowanej pozycji szeroko omawiany, szczególnie w kontekście możliwości bezpośredniego docierania do wyborcy, co bez wątpienia jest jej dużym walorem. Warto przy tym podkreślić, że poruszono nie tylko wątek relacji media i polityka, ale również kondycji dziennikarstwa w Polsce w ogóle.

W książce nie zabrakło także rozmowy o sytuacji branży public relations w Polsce. W dyskursie publicznym dużo pisze się ostatnio o public relations zwłaszcza w kontekście bardzo negatywnego postrzegania tego pojęcia. Jeśli odwołać się do teorii, utożsamianie public relations z działaniami nieetycznymi czy też propagandowymi nie ma uzasadnienia. Jednakże w polskim dyskursie używanie sformułowania "sztuczka piarowska” stało się już niemal codziennością. Określenia takie pojawiają się niestety także w recenzowanej tu pozycji. Mistewicz do działań PR w Polsce odnosi się krytycznie. Jednak krytyka ta zdaje się konstruktywna i podparta argumentami, z którymi oczywiście można się nie zgadzać, ale trudno im odmówić logiki. Kardynalnym zarzutem wobec całej branży w Polsce jest to, że brakuje osób, które poszukują nowych rozwiązań, wyprzedzają nowe trendy w komunikacji. Dominują natomiast rzemieślnicy, którzy po prostu pró- 
bują się wybić. To, zdaniem Mistewicza, nie jest droga prowadząca do sukcesu, a przynajmniej tego długofalowego, natomiast jest przyczyną bardzo niekorzystnego wizerunku całej branży. Jednakowoż czynników, które wywołują taki stan rzeczy, jest co najmniej kilka. Przede wszystkim niski poziom kształcenia na kierunkach związanych z marketingiem i public relations. Stąd też Mistewicz poleca studiowanie socjologii, psychologii społecznej, politologii i dziennikarstwa - to są kierunki niezwykle przydatne zwłaszcza w przypadku marketingu narracyjnego, w którym wszechstronna wiedza ma duże znaczenie.

W rozmowach Karnowskiego z Mistewiczem jest kilka kwestii, które skłaniają do polemiki. Można tu wymienić choćby to, że prezentowane tu dwie całkowicie odmienne perspektywy patrzenia na politykę tworzą wrażenie, jakby w tym złożonym świecie wszystko było czarne albo białe. Innymi słowy, polityka jest pełna wielkich planów, reform i idei lub jest sprawnie opowiedzianą historią. Czytelnik może więc odnieść wrażenie, że przekaz medialny dotyczący polityki jest fikcją, jest wyreżyserowanym spektaklem, tylko na potrzeby zwiększania poparcia społecznego. Wydaje się, że wbrew pozorom oba prezentowane w książce stanowiska mają ze sobą wiele wspólnego. Należy wyjść od tego, że marketing i wszelkie działania komunikacyjne, jeśli mają być zgodne z etyką i z celami, do osiągnięcia których zostały powołane, muszą mieć treść, inaczej mówiąc - powinny mieć pokrycie w rzeczywistości. Idąc tym tokiem rozumowania, szybko dochodzimy do wniosku, że plany polityczne powinny być precyzyjnie i rzetelnie komunikowane, zdobywanie i utrzymywanie władzy jest natomiast bardzo naturalne, tak samo jak to, że politycy powinni korzystać z pomocy specjalistów w zakresie komunikacji. W tym miejscu właśnie łączą się stanowiska Karnowskiego i Mistewicza.

Wśród analizowanych tematów jeden szczególnie należy podać w wątpliwość. Mowa tu o politycznym konsultingu. Trzeba zwrócić uwagę, że Mistewicz ma bogate doświadczenie zawodowe związane przede wszystkim z Francją, ta perspektywa w dużym stopniu kształtuje jego spojrzenie na komunikowanie polityczne. Pojawia się zatem uzasadnione pytanie, czy sytuacje, o których pisze Mistewicz, związane z przygotowywaniem przekazów dziennych, omawianiem podejmowanych działań, opracowywaniem strategii komunikacyjnej, czy inaczej - konstruowaniem historii, narracji, rzeczywiście w Polsce występują. Należy bowiem zwrócić uwagę, że w literaturze przedmiotu istnieje widoczna luka w zakresie badań, których przedmiotem byłaby współpraca polityków i partii politycznych ze specjalistami z zakresu komunikacji i public relations. Innymi słowy, poruszamy się w podejmowanych analizach bardziej w obrębie pewnych domysłów, przecieków medialnych, ewentualnie pewnych norm i zasad w działaniach komunikacyjnych. Badania takie, oczywiście z punktu widzenia rzetelnego opisu politycznej rzeczywistości, są konieczne, jednakże w Polsce trudne do realizacji z dwóch zasadniczych powodów. Wynika to po pierwsze ze stosunkowo niskiej świadomości związanej z potrzebą permanentnego komunikowania działań po- 
dejmowanych przez partię, zwłaszcza rządzącą, i po drugie - z braku zaufania samych polityków do tego typu badań, a także tego, jak ich wyniki zostaną odebrane przez opinię publiczną. Jeśli zatem wnioskować z obserwacji sceny politycznej, analiz sytuacji kryzysowych partii czy poszczególnych polityków, czy też sposobu komunikowania ważnych społecznie kwestii, można odnieść wrażenie, że w Polsce współpraca ze specjalistami z agencji komercyjnych występuje przede wszystkim w okresie kampanii wyborczych lub w momentach ewidentnie dla partii czy polityków kryzysowych pod względem wizerunkowym. Współpraca taka nie ma również charakteru permanentnego. Jeśli więc Dennis Johnson [2007] pisze, że w polityce nie ma miejsca dla amatorów, to co do zasady - ma rację. Jednakże wydaje się, że w Polsce większość polityków nie korzysta z usług profesjonalistów z zakresu komunikacji lub też korzysta z nich, ale w bardzo niewielkim zakresie. W związku z powyższym rodzi się przekonanie, że wyobrażenie przeciętnego obywatela, spotęgowane także rozmowami Karnowskiego i Mistewicza na temat sztabu PR-owców wokół polityków, może być nieco mylne. Istnieje zatem możliwość, że ulegamy zbiorowemu złudzeniu, że polską polityką rządzą specjaliści od PR. Tymczasem należy podkreślić, że polski rynek polityczny znacząco różni się od choćby amerykańskiego, do którego tak konsekwentnie się odwołujemy.

Fakt, że książka zmusza do refleksji, rodzi pytania i polemiki, należy uznać za jej duży atut. Forma, w jakiej praca jest przedstawiona czytelnikowi, inspiruje do bardziej świadomej analizy życia publicznego, pokazuje niezwykłą złożoność wielu wzajemnych zależności, najnowsze trendy w komunikacji, ale też obnaża słabości komunikowania politycznego w Polsce. Rozmowy Karnowskiego z Mistewiczem poszerzają spojrzenie na wiele istotnych zjawisk życia społecznego, skłaniają do bardziej wnikliwych obserwacji. Na koniec należy dodać, że książka miała doskonałą kampanię promocyjną.

Anatomia władzy ... bez wątpienia będzie szczególnie interesująca dla studentów nauk politycznych, socjologii czy dziennikarstwa, ale także dla czytelników z zainteresowaniem śledzących polskie życie polityczne.

\section{Bibliografia}

Anatomia władzy. Mistewicz kontra Karnowski. 2010. Warszawa: Wydawnictwo Czerwone i Czarne.

Wincławska Maria. 2010. Unia Wolności. Przypadek partii okresu transformacji. Warszawa: Scholar.

Johnson Dennis. 2007. No Place for Amateures. London: SAGE.

Barbara Brodzińska-Mirowska

(Uniwersytet Mikołaja Kopernika w Toruniu) 